w kręgu rodzinnym. Wierzył głęboko, że jeżeli zadba o wychowanie swych dzieci, to one mu się za to odwdzięcza "na stare lata" ${ }^{6}$. Stało się jednak inaczej i na tym polegał tragizm Godoya jako ojca. Godoy boleśnie odczuł tę prawdę, kiedy po wyjeździe Pepy z Paryża (1834) pozostal sam. Nikt się nim wówczas nie interesował i na dodatek cierpiał upokarzająca biedę. Podobno najlepiej czuł się w otoczeniu dzieci z ulicy, z którymi rozmawial, brał je na kolana, pozwalał dotykać swej laski i siedząc na ławce całymi godzinami obserwowal jak się bawią ${ }^{67}$. Godoy zawsze darzył sympatia dzieci. Obce kochał niemal jak swoje. Udowodnił to jeszcze w Rzymie, po przeprowadzce do willi Campitelii. W stosunkowo małym domu zamieszkałym przez kilka rodzin pokornie znosił nie tylko ciasnote, ale obecność trzech rozbrykanych synów Magdaleny Tudó. „Mieszkają nad moim pokojem i nie mogę nie słyszeć gier, biegów i krzyków, jakie wydobywają z siebie - narzekał do Pepy, ale zaraz potem dodawał ze spokojem: - rozumiem, to zupełnie naturalne w ich wieku" ${ }^{8}$. Jego wrażliwość wobec potomstwa sióstr Pepy (Socorro i Magdaleny) szła tak daleko, że znając trudną sytuację materialną rodziców partycypował w kosztach ich utrzymania ${ }^{69}$.

Grażyna Kartowska

Bydgoszcz

\title{
Wizerunek matki prezentowany przez Klementynę z Tańskich Hoffmanowa na łamach pisma „Rozrywki dla dzieci”
}

Artykuł ten jest próbą przedstawienia wizerunku matki, jaki stworzyła swoją ręką Klementyna z Tańskich Hoffmanowa, i który przedstawiła na łamach wydawanego przez siebie pisma pt. Rozrywki dla Dzieci. Zanim jednak zaprezentujemy wizerunek ${ }^{\natural}$, czyli opiszemy słowami postać matki nakreślony przez Hoffmanowa, należy poddać analizie warunki społeczno-polityczne, jakie wpłynęły na ukształtowanie się tegoż wizerunku w społeczeństwie polskim w XIX wieku.

Niewatpliwie obraz matki $w$ tym czasie był $w$ znacznym stopniu lustrzanym odbiciem ideału kobiety, jaki wytworzył się w mentalności społecznej na przestrzeni XIX wieku. Miejsce i rolę kobiety w społeczeństwie w tym czasie wyznaczały jej obowiązki i funkcje wynikające z jej powołania, tj. żony - wiemej towarzyszki mężczyzny, wzorowej gospodyni zarządzającej domem i wychowującej dzieci matki. Powszechny w tym czasie pogląd, że opatrzność i sama natura wskazywała tej połowie rodu ludzkiego jej właściwe powołanie, kształtował ideał kobiety wyposażonej w takie cechy i zalety charakteru, jak miłość, wierność, skromność, pobożność, gospodarność, dbałość o dom i rodzinę ${ }^{2}$. Wymienione cechy i zalety tworzace obraz ideału kobiety, były jednocześnie wykładnikiem wzorowej żony i matki. Zbudowany w oparciu o ten ideał wizerunek matki, to wrażliwa, ciepła, skromna, pobożna i rozsądnie myśląca kobieta, świadoma swej społecznej roli, postępowaniem służąca za przykład dla swoich dzieci. Zwłaszcza jeśli chodzi o córki, matka miała świecić przykładem i w ten sposób przygotować je do przyszłej roli żony i matki. Warunki historyczne nałożyły na kobietę dodatkowo rolę

66 AHN, 2832, Manuel Godoy do Pepity Tudó, Rzym, 19.12.1818.

${ }^{67}$ E. Rúspoli y Morenés, La marca de exilio. La Beltraneja, Cardoso y Godoy, Madryt 1992, s. 192-221.

68 AHN, 2834, Manuel Godoy do Pepity Tudo, Rzym, 8.07,1819.

69 Ibidem, 8.07.1819.

WIZERUNEK [w:] Maty słownik jezyka polskiego, wyd. IX, Warszawa 1993, s. 899.

${ }^{2}$ D. Rzepniewska, Kobieta w rodzinie ziemiañskiej w XIX wieku Królestwo Polskie, [w:] Kobieta $i$ spoteczeństwo na ziemiach polskich w XIX wieku, pod red. A. Żarnowskiej i A. Szwarca, Warszawa 1990, s. 38. 
emisariuszki polskiej tradycji i strażniczki języka ojczystego. Właśnie ta cecha matki, w sposób szczególny akcentowana była na przestrzeni XIX wieku, z uwagi na ciężkie doświadczenia zniewolonego i walczącego o swą tożsamość narodu polskiego.

Jedynym czynnikiem spajającym naród polski w określona całość w tej dobie była wspólna dla wszystkich dzielnic kultura, pozwalająca utrzymać więź między Polakami żyjącymi w trzech zaborach, mimo trwajacego dziesiątki lat rozbicia politycznego.

Systemy oświatowo-wychowawcze, dominujace na ziemiach polskich u schyłku XIX i na początku XX wieku, różniły się od siebie znacznie na terenie poszczególnych zaborów. Jednak niezależnie od tych różnic polityka zaborców ukierunkiowana była na jeden cel: wynarodowienie społeczeństwa polskiego, począwszy od niszczenia polskiej gospodarki a na rodzinie polskiej kończąc.

Fakt ten odbił się wyraźnie na kierunkach rozwoju i stanie polskiej myśli pedagogicznej. Jedyna możliwą i skuteczna forma edukacji w tych warunkach mogło byé wychowanie i kształcenie rodzinne dziecka ${ }^{3}$.

Wychowanie w rodzinie utożsamiano $\mathrm{z}$ racji jego zadań i kompetencji ze wspólnota narodowa, jej historia i losem oraz wartościami, takimi jak: umiłowanie wolności, gotowość do poświęceń w imię jej zachowania i obrony, honor, tolerancja - trwałymi spoiwami polskiej tradycji i tożsamości narodowej.

Na czoło wysuwala się zatem sprawa wychowania patriotycznego młodego pokolenia. Zadanie to spełnić miała rodzina polska, a w głównej mierze matka, gdyż dom był jedynym prawdziwym miejscem wychowujacym $w$ duchu polskości ${ }^{4}$.

Ważnym środkiem w realizacji ówczesnych koncepcji pedagogicznych okazała się prasa polska, choć w znacznym stopniu podlegająca ostrej cenzurze ${ }^{5}$. Prasa polska, a zwłaszcza jej pracownicy odegrali rolę faktycznego koordynatora działalności Polaków. Na łamach czasopism prezentowano nowe koncepcje edukacyjne, prowadzono polemiki na temat kierunku rozwoju spolecznego, udzielano porad wychowawczych, przedstawiano obraz wychowania rodzinnego i sposoby jego realizacji.

Prekursorka poradnictwa wychowawczego prowadzonego na lamach czasopisma byla Klementyna z Tańskich Hoffmanowa ${ }^{6}$. Jej inwencja twórcza, talent pisarski i lagodna perswazja nie tylko przemawiały do wyobraźni czytelnika, ale ukazywały im poglądy autorki na wychowanie moralne, edukację patriotyczną, a przede wszystkim życie rodzinne.

Ważnym elementem w propagowaniu pogląów pedagogicznych Hoffmanowej dotyczących znaczenia i zadań rodziny w procesie wychowania było pierwsze czasopismo dla dzieci i młodzieży pt. Rozrywki dla Dzieci. Pismo ukazywało się co miesiąc w latach 1824-1828. Tańska była głównym redaktorem i autorem czasopisma. Można powiedzieć, że zapełniała sama wszystkie numery. Główne założenia pisma ujęla redaktorka w słowach: ,nic obcego, nic cudzego (chyba bardzo piękne rzeczy) miejsca w moim piśmie nie znajda; będzie zupełnie poświęcone narodowości, cnocie, dzieciom"? Hoffmanowa stworzyła pismo o przemyślanej koncepcji, w której wszystko było celowe. Układ redakcyjny Rozrywek... był mało skomplikowany. W sześciu działach miesięcznika redaktorka starała się poruszać aktualne problemy wychowawcze, wpływać i kształtować moralne postawy rodziców, a przede wszystkim nakreślić wizerunek wzorowej matek. Uważala bowiem, że cnoty i oświecenie przyszłych członków społeczeństwa zależą w głównej mierze od starań matki - Polki.

${ }^{3} \mathrm{~K}$. Jakubiak, Edukacja rodziców w polskiej refleksji i praktyce pedagogicznej XIX i XX wieku do 1939 roku, [w:] Wychowanie w rodzinie polskiej od schylku XVIII do polowy XIX wieku, pod red. K. Jakubiaka i A. Winiarza, Bydgoszcz 2000, s. $113-132$.

${ }_{4}^{4}$ A. Zieliński, Poczatek wieku - przemiany kultury narodowej w latach 1807-1831, Łódź 1973, s. 129.

5 A. Jazdon, Pruskie prawo cenzuralne, prasowe i proceduralne $w$ Wielkim Księstwie Poznaniskim w pierwszej polowie XIX w., „Roczniki Biblioteczne” 1989, z. 1-2, s. 90.

${ }^{6}$ Klementyna z Tańskich Hoffmanowa (1798-1845) [w:] Slownik Pedagogów Polskich, pod red. W. Bobrowskiej-Nowak i D. Dryndy, Katowice 1998, s. 68-69.

${ }^{7}$ K. z Tańskich Hoffmanowa, Pamiętniki, [w:] Pisma pośmiertne, Berlin 1849, s. 123. 
Tak pisała w swym pamiętniku: „Kobieta jest użyteczna dla świata i jako żona a cóż dopiero, kiedy zostanie matką"8 i „Jeżeli Bóg da Ci [...], być matka, strzeż się tej powszechnej u nas zarazy, dawania dzieciom nauk w obcych językach"”.

Wizerunek dobrej, troskliwej, świadomej swej roli matki przedstawiła Hoffmanowa na łamach „Rozrywek...”, w dziale pt. „Wiadomości mogace być matkom przydatne”. Zawierały one pisane przez Hoffmanową listy matki o wychowaniu córek. Adresowała je do matek, którym poprzez fikcyjna osobę pisząca do starszej siostry przekazuje zasady i metody edukacji siedmio-, ośmio- i dziesięcioletnich dzieci. W Listach... cel wychowania był szeroko uspołeczniony, a jego realizacja miała sprawić według autorki, że dziecko po osiągnięciu pełnoletności zdolne byłoby „przyłożyć się do sprawy społecznej” i „[...] miało los niepodległy w sobie, kawałek pewnego chleba" ${ }^{10}$.

Macierzyństwo, było zdaniem Tańskiej, godne szczególnej pochwały bowiem „,...] kiedy Bóg parze jakiejś pobłogosławi, pozwala odrodzić się jej w młodych latoroślach" "I. Uważała, że matka powinna karmić niemowlę własną piersią, nie tylko ze względu na prawidłowy rozwój fizyczny dziecka, poprzez tak bliski kontakt matki z dzieckiem w pierwszym okresie jego życia wywiazuje się więź, której nie sposób wypracować w żaden inny sposób. Jednocześnie twierdziła, że matka nie może być zbyt czuła, a powinna rozsądnie szafować uczuciami. Miłość macierzyńska powinna kierować się prawidłami: ,[...] kochaj swoje dzieci”, ale ,[...] niech żadne przywiazanie twoje, [...] żadne uczucie nie przechodzi granic umiarkowania i rozsądku" ${ }^{2}$. Pojęciu czułości poświęciła Hoffmanowa jeden z listów, przedstawiając jako opozycję do powszechnie panującego pojęcia czułości swoją własną definicję czułości: ,„...] ja chcę - pisze w listach - żeby one malo dla siebie wymagając, wiele dla drugich czynily, [...] chcę, żeby nie tylko mogły patrzeć na cierpienia, śmierć, nieszczęścia osób ukochanych, ale żeby pociechy, odwagi, rady, udzielić im potrafiły [...]"13. Autorka Wiadomości..., była zdania, że wskazówek i metod wychowania szukać trzeba we własnym sercu i mądrości, a zarazem pilnie słuchać rad praktycznych tych doświadczonych kobiet, które dobrze wychowały własne dzieci.

Matka powınna stosować różnorodne metody wychowawcze, ponieważ ,kaźde prawie dziecko z innym charakterem się rodzi, z każdym inaczej obchodzić się wypada" ${ }^{14}$. Jej zdaniem ,„[...] jedna tylko matka rozróżnić może te cieniowania i na nich gruntować sposób dalszego wychowania" ". Matka powinna dostrzegać różnice w naturze swych dzieci, a także ich drobne skłonności i odpowiednio do nich dobierać metody wychowawcze. Uważała, że skłonności należy zwalczać jak najwcześniej ,[...] nie sądź rzeczą mało ważna, zgłębianie wczesne skłonności dzieci twoich [...] Wszystkie nasze skłonności moga łatwo w nałogi się przemienić i dlatego jeśli złe, trzeba je zbijać skoro się okaża" ${ }^{16}$. Najlepsza okazją do obserwacji dziecka była według Tańskiej zabawa, ,dlatego nie trzeba w ich zabawie krępować wolności dzieci; pozbawić by się można najlepszego sposobu dostrzegania tego, co się w ich umyśle i w ich duszy dzieje" !?.

Jedna z metod wychowawczych był odpowiednio dobrany system nagród i kar. Zdaniem autorki Listów... kara i nagroda muszą być odpowiednio dostosowane do temperamentu każdego dziecka. Niezależnie jednak od tego uważała, że karać należy z ,zimna krwią i z okazaniem wstrętu" "18; jako środka represyjnego zalecała używać niezadowolenia, pozbawienia dziecka tkliwych oznak miłości „kiedy, która zbłądzi, nie przyjmuję jej pieszczot, obchodzę się z nią zimno"'9. Nagrody radziła

Jbidem, s. 16.

' Ibidem, s. $69-70$.

10 P. Chmielowski, Klementyna z Tańskich Hoffmanowa - zarys biograficzno-pedagogiczny. Życiorysy stawnych Polaków i Polek, Petersburg 1898, s. 52.

" K. z Tańskich Hoffmanowa, Listy matki o wychowaniu córek swoich, „Rozrywki dla Dzieci”, 1824, nr 34, s. 16.

12 lbidem, nr 23, s. 270.

13 Jbidem, 1827, t. JV, nr 22, s. 242-243.

14 Ibidem, nr 29, s. 337.

15 Ibidem, nr 29, s. 337.

16 Ibidem, 1827, t. V1l, nr 41, s. 252-253.

17 Ibidem, nr 41, s. 253.

18 Ibidem, nr 27, s. 168.

19 Ibidem, nr 20, s. 119. 
stosować przy różnych okazjach, gdyż ,[...] każdy od kolebki do grobu za pochwałą i nagroda goni i że o to jedynie idzie, żeby dzieciom wskazać zawsze cel szlachetny i prawdziwy" ${ }^{20}$. Tańska uważała, że charakter można ukształtować systematycznym oddziaływaniem na psychikę i przemyślanym kierunkiem pedagogicznej pracy rodziców. Zapewne dlatego szczególnie wysoko ceniła przykład rodziców, ponieważ dzieci mają wielką skłonność do naśladowania. Radziła więc rodzicom zdobycie się na nienaganne postawy moralne. Nie pochwalała długich pouczeń bez poparcia ich dobrym przykładem, bo jak pisała na nic się one wówczas nie przydaja, ,[...] okoliczność silniej od słów przemawia i użycza dziecięciu oczywistego przekonania, jakim to złem jest każde przestępstwo" 21 .

Przejmując jako ideał niewiasty osobę potrafiąca zając się domem, opieka nad dziećmi, będąca podpora i ozdoba męża i domu, dla ułatwienia budowy takiego wzoru przyjęła Tańska za niezbędne kierowanie się przez kobiety zasadami wiary chrześcijańskiej: ,[...] usposobić dzieci na prawdziwe chrześcijanki, na rozsądne, światłe niewiasty, na dobre Polki i gospodynie" 22 .

Hoffmanowa nakładała również na matkę obowiązek wychowania w duchu chrześcijańskim, to matka powinna przekazywać wiedzę, jak żyć po chrześcijańsku, gdyż tylko ona ,[...] przeznaczeniu swemu odpowiadajac, przez te kilka lat wpoić potrafi w syna swojego religię i wszelkie cnoty" ${ }^{23}$. Dzięki wychowaniu religijnemu ,„...] ukształciwszy serce córki, nadawszy jej przymioty, talenta, umiejętności potrzebne kobiecie" ${ }^{24}$, w późniejszym okresie nauki ten wysiłek stać się miał mocną podstawą w dorosłym życiu.

W swej koncepcji wychowawczej Hoffmanowa wysuwała na pierwszy plan kształcenic $w$ duchu obywatelskim, hołdowanie tradycjom kulturalnym ojczyzny, szacunek do przeszłości i jednocześnie troskę o przyszłość polskiego narodu. Na te wlaśnie treści, służące rozumnemu wychowaniu, podporządkowanemu formowaniu patriotycznej osobowości dziecka zwracała uwagę autorka wspomnianych Listów.

Niezawodnym kluczem do rozbudzenia uczuć narodowych i gwarancją uzyskania zamierzonego rezultatu była edukacja $w$ języku ojczystym. Matka miała poprzez wychowanie patriotyczne objąc los własnych dzieci, a w rezultacie przyszłość ojczyzny. W tym też kontekście zalecała matkom, aby w życiu codziennym, a zwlaszcza w nauce i zabawie czuwały nad tym, żeby ich dzieci posługiwały się językiem ojczystym. Widziała w tym Tańska jedyną szansę na zabezpieczenie i przetrwanie polskiego narodu. Specyfikę wychowania patriotycznego, wyraziła Hoffmanowa nie tylko we wspomnianych już Listach..., realizowała ja też $\mathrm{w}$ dziale pt. Wspomnienia narodowe, $\mathrm{w}$ których przedstawiła m.in. biografie słynnych postaci historycznych. Budzeniu i podtrzymaniu patriotyzmu służyć miały również zamieszczane na lamach Rozrywek...: Wyjatki stuzace uksztattowaniu serca $i$ stylu.

Mówiąc o edukacyjnej roli matki podkreślała, że dzieci należy uczyć krótko a gruntownie, czyli mało a dobrze. Dlatego za jeden z najskuteczniejszych środków nauki uważała rozmowę przeprowadzoną $z$ dzieckiem przez matkę: , ,[...] rozmowa podobna jest nierównie od wszelkich książek dla dzieci użyteczniejsza naprzód powstaje z przedmiotów dziecię otaczających jest więc z jego stanem i przeznaczeniem zgodna" 25 .

Kreśląc portret matki - rodzicielki, opiekunki - piastunki, wychowawczyni postaw moralnych, w szczególny sposób podkreślała rolę matki jako nauczycielki polskości. Właśnie ta powinność matki wysuwała się na plan pierwszy w okresie zaborów. Rolę tą dostrzegali również przedstawiciele polskiej kultury narodowej podkreślając, że wychowanie i moralna postawa przyszłych Polaków zależy od

\footnotetext{
${ }^{20}$ Ibidem, 1827, t. IV, nr 27, s. 109.

${ }^{21}$ Ibidem, 1827 , t. IV, nr 20, s. $116-117$.

${ }^{22}$ I. Kaniowska-Lewińska, Twórczość dla dzieci i mlodzieży Klementyny z Tańskich Hoffmanowej, "Zeszyty Naukowe Wyższej Szkoly Pedagogicznej w Opolu", seria B, Studia i Rozprawy, nr 6, Opole 1964, s. 195.

${ }^{23}$ Ibidem, nr 35, s. 269.

24 Ibidem, nr 35 , s. 268.

${ }^{25}$ K. z Tańskich Hoffmanowa, Ku poczciwemu zywotowi dziecię wychowane być ma, ,Szkoła Polska" 1849, t. 2 , nr 32 , s. 118
} 
charakteru, upodobań i światłości kobiet: „[...] Moga burzyciele zagrabiać narody, zbierać i niszczyć te księgi, w których zapisane sa plemiona ludzkiego szczęścia i klęski, ale nie zatłumia w ustach matek tych pieśni, którymi one przypominają dzieciom, że miały ojczyznę"26.

Nakreślony przez K. z Tańskich Hoffmanowa wizerunek matki odpowiadał ówcześnie lansowanemu ideałowi kobiety. Takim ideałem miała być przykładna żona, troskliwa i rozumnie wychowująca matka, nauczycielka młodego pokolenia, świadoma swej społecznej roli Polka. Cechować ja miały oparte na dekalogu: bezwarunkowa miłośc, dobroć, wybaczenie ${ }^{27}$.

Hoffmanowa nakreśliła niezależny od podziałów społecznych wspólny tak dla drobnomieszczan, szlachty, robotnika czy chłopa obraz matki, co ważne, z wyraźnie zarysowaną cechą Matki - Polki. Na pierwszy plan wysuwa podstawowe i instynktowne funkcje matki, matka ma przede wszystkim kochać i wychowywać ${ }^{28}$. Niewatpliwie inspiracja dla Hoffmanowej były idee dotyczące wychowania w rodzinie formulowane w tym czasie przez polskich pedagogów, a bodźcem do stworzenia takiego wizerunku matki sytuacja polityczno-społeczna, w jakiej przyszło rodzinie polskiej wychowywać młode pokolenie Polaków.

Tworząc wizerunek matki - nauczycielki, wychowawczyni, przyjaciółki i powiernicy, stworzyła Hoffmanowa uniwersalny portret matki, odpowiadający duchowi XIX wieku, ale aktualny do dnia dzisiejszego.

Z kolei ideał kobiety, jaki wykształcił się na przestrzeni XIX wieku uległ diametralnej zmianie $\mathrm{w}$ wieku XX, nie jest on już tożsamy z wizerunkiem matki. Obecnie kobieta jest postrzegana nie tylko w roli żony i matki, a co ważniejsze nie tylko to określa jej wartość społeczna.

Opis cech osobowych matki, a więc wrażliwość, skromność, bogobojność, oraz jej powinności i zadań wynikających z jej wychowawczej i kształcacej roli, jakie wyznaczyła Hoffmanowa matce, doskonale współgra z wizerunkiem matki naszkicowanym przez myslicieli europejskich: „[...] Mama to pokarm, miłość i ciepło światła. Być przez Nią kochanym to to samo co mieć dom, być żywym, zakorzenionym" 29 , „ona otworzyła moje serce na piękno przyrody; Ona obudziła ze snu mój umysł, rozszerzyła horyzonty a jej wrażliwość wywarła decydujacy wpływ na kierunek mego życia" ${ }^{30}$.

\section{„Przyjaciel Młodzieży” (1909-1939) jako źródło w badaniach nad dziejami wychowania katolickiego w początkach XX wieku}

„Przyjaciel Młodzieży” był miesięcznikiem wydawanym w Poznaniu', drukowanym przez trzydzieści lat, w okresie pomiędzy 1909 a 1939 rokiem. Początkowo miał objętość czterostronicowej broszury, ale po 1920 roku ukazywał się w objętości dwudziestukilku stron. Pismo nie stało na wysokim

${ }^{26}$ Cyt. za S. Gawlik, Dziedzictwo pedagogiczne Klementyny z Tańskich Hoffmanowej, Opole 1995, s. 28.

${ }^{27}$ M. Bienenstock, Pedagogika Klementyny z Tańskich Hoffmanowej na tle wieku, „Wychowanie w Domu i w Szkole", Warszawa 1914, s. 4, s. 364.

${ }_{28}$ J. Sobczak, Przejawy zainteresowania wychowaniem rodzinnym $w$ pracach niektórych polskich pisarzy i pedagogów u schylku XVII i w pierwszej polowie XIX wieku, [w:] Zeszyty Naukowe WSP, Studia Pedagogiczne 1992 , z. 18 , s. $95-109$. s. 5 .

${ }^{29}$ E. Fromm, Matka, [w:] Mama najdroższa jedyna, wybór tekstów i obrazów Helen Exley, Częstochowa 1997,

30 I. Kant, Matka, tamże, s. 7.

1 Autorowi wiadomo, iż obok tego pisma istniało inne o identycznym tytule, ale wydawane w Grudziądzu. 